\title{
Microworlds with Different Pedagogical Approaches in Introductory Programming Learning: Effects in Programming Knowledge and Logical Reasoning
}

\author{
Joana Martinho Costa \\ Instituto Universitário de Lisboa (ISCTE-IUL), ISTAR-IUL, Lisboa, Portugal \\ E-mail: joana.martinho.costa@gmail.com
}

Thesis summary

Keywords: microworlds, introductory programming learning, 4C/ID model, expository teaching

Received: January 21, 2019

\begin{abstract}
This paper presents a summary of doctoral thesis that evaluates the using of Alice microworld combined with different pedagogical approaches to learn introductory programming, specifically in programming knowledge and logical reasoning variables. The results suggest that when microworlds are combined with the 4C-ID instructional model there are positive effects in learning to program a computer, but they have no impact if an expository method is used. However, given the limited number of sampled subjects in this thesis, this topic should be further researched. It is necessary to understand to what extent, measurable, the use of certain teaching methods with or without association with microworlds, influence the results of students in knowledge and logical reasoning.
\end{abstract}

Povzetek: Opisano je doktorsko delo na področju poučevanja osnovnih programskih veščin.

\section{Introduction}

The scientific community has been developing several proposals to overcome the inherent difficulties in the initial learning of computer programming. One of the solutions is the use of microworlds. Faced with this problem, some solutions have been developed over the past few years to help overcome student difficulties. One of the proposed solutions is composed of the use of microworlds, such as Alice. This software aims to help and motivate students to learn how to program and was created about 15 years ago. Since then, it has been updated and several versions have emerged [1].

The Alice software is considered a microworld for programming because it respects the characteristics of Papert's microworld [2], namely: i) the possibility of creating simple examples in the microworld itself, in this case programming examples; ii) there should be no obstacles in the manipulation of the microworld, with the possibility of creating activities, games and art within the microworld; and iii) the content needed for learning should be able to be defined within the microworld.

The present research organized into a thesis [3] with four sequential chapters, had the objective of understanding the effects of using Alice microworld, in programming learning when associated with certain pedagogical methods, specifically in the programming knowledge and in the logical reasoning, with a focus on vocational education at Portugal.

\section{Methodology}

The research process began with the typification of the Alice software into microworld in order to extend the thesis conclusion to other microworlds.

The next step was conducted a systematic literature review and meta-analysis in order to understand the effects of Alice in programming learning on previous studies [4]. The combination of studies indicated promising results in the field $(\mathrm{d}=0.541)$, but presented some weaknesses, where we highlight: (i) significant variation in data collection instruments, (ii) and the design of the studies, which do not specify the teaching strategies used to teach computer programming. In addition, there was no analysis of whether the use this microworld has a different impact has when students differ in cognitive and social characteristics, as these variables were also not isolated in any of the studies considered in the metaanalysis.

Therefore, we pursued the research by building a valid and reliable instrument, in Portuguese language, to evaluate the initial learning of programming in quasiexperimental studies [5]. This instrument was constituted by multiple-choice and development questions and the difficulty level of the items was based on Bloom's Taxonomy. The test was subsequently validated by a group of specialists and submitted to a pilot-group. This process concluded that the instrument is valid and reliable (alfa $=0.837)$.

Lastly, we developed two quasi-experimental studies.

In the first one [6], the experimental group $(n=11)$ used programming concepts with the Alice software and pseudocode, while the control group $(n=11)$ learned the same concepts without resorting to software. Both were 
taught using expository teaching, the most commonly used method in Portugal [7]. In the first experimental study, based on the characteristics of a quasi-experimental design, we defined the following procedures:

1) Data collection on the characteristics of the participants, application of a survey about the interest in programming and application of the Echelle Collective de Développement Logique (ECDL) [8], a scale that classifies the student thinking according to the five stages of Jean Piaget's theory on cognitive thinking.;

2) Experimental treatment: Introductory programming learning using an expository teaching combined with Alice microworld in the experimental group and the same conventional model without Alice, for four weeks with seven hours of programming per week

3) Application of the created test [5] after experimental treatment to both groups.

In the second study [9], computer program knowledge and development of logical reasoning were compared between two groups, which differed in logical reasoning and socioeconomic status, after they learned programming with Alice microworld associated to the Four Component Instructional Design Model (4C-ID). We followed next procedures:

1) Data collection on the characteristics of the participants, application of a questionnaire on the interest of programming and application of the ECDL [7];

2) Experimental treatment: Initial programming learning using the 4C/ID instructional model combined with Alice software, for eight weeks with 30 classes of 50 minutes, in both groups;

3) After experimental treatment, application of the knowledge test and the ECDL to both groups.

\section{Results}

In the first study, the average score in the programming test, applied after the experimental treatment when covaried with the average score on the Logical Development Scale, applied before to the experimental treatment, was positive in both groups with no statistically significant difference between them $(F(1,19)=0.984 ; p>$ $0.05)$. When the ECDL covariable is maintained at its average value (11.95), the group that used Alice obtained a mean result in the programming test $(6.073+-0.834)$ lower than the group that exclusively used pseudocode $(7,290+-0.834)$. The analysis of planned contrasts between the experimental and control group reveals that the differences between the approaches (Alice with pseudocode or exclusive pseudocode) are not significant $(\mathrm{t}(19)=0.992 ; \mathrm{p}>0.05)$.

In the second study, the average score in the programming test, applied after the experimental treatment, when covaried with the average score on the Logical Development Scale (ECDL) prior to experimental treatment was positive in both groups, with no statistically significant difference between them $(p>0.05)$. Total ECDL score before and after experimental treatment differed positively in the control group $(n=8$; $p<0.05)$ and experimental group, although here the difference was not statistically significant $(\mathrm{n}=6 ; \mathrm{p}>0.05)$. The experimental group in this second study with lower socioeconomic status obtained the highest computer test average among the four groups in the two studies.

\section{Conclusions and future work}

This study aimed to understand the effects of the use of microworlds, when associated with different teaching methodologies, in the introductory programming learning. To answer this question, we used Alice microworld in quasi-experimental work.

The results suggested that when Alice microworld is combined with the 4C-ID instructional model there are positive effects in learning to program a computer, but this software have no impact if an expository method is used. However, given the limited number of sampled subjects, this topic should be further researched.

Finally, we suggest conducting experimental research that continues the work initiated in this thesis. It is necessary to understand the extent, measurable, the use of certain teaching methods with or without association with microworlds, influence the results of students in knowledge and logical reasoning. In future research, the same measuring instruments present in this study should be used, in groups with similar characteristics, in order to compare the results obtained with those described in this thesis.

\section{References}

[1] Alice Project. (2018). Alice - Tell Stories. Build Games. Learn to Program. Retrieved from http://www.alice.org.

[2] Papert, S. (1985). Different visions of logo. Computers in the schools. Interdisciplinary Journal of Practice, Theory, and Applied Research, 2(2-3), 3-8.

[3] Costa, J.M. (2019). Utilização do micromundo Alice na aprendizagem da programação: Efeitos sobre os conhecimentos e o raciocínio lógico (Unpublished doctoral dissertation). Institute of Education, University of Lisbon, Lisbon, Portugal.

[4] Costa, J. M., \& Miranda, G. L. (2017). Relation between Alice software and programming learning: A systematic review of the literature and metaanalysis. British Journal of Educational Technology, 48(6), 1464-1474.

doi: https://doi.org/10.1111/bjet.12496

[5] Costa, J. M., \& Miranda, G. L. (2017) Desenvolvimento e validação de uma prova de avaliação das competências iniciais de programação. RISTI - Revista Ibérica de Sistemas e Tecnologias de Informação, 25, 66-81. https://dx.doi.org/10.17013/risti.25.66-81

[6] Costa, J. M. (2018). Using Alice Software with the Expository Method: a pilot study. International Journal of Engineering and Technology, 10(6), 
1681-1686.

doi:

https://doi.org/10.21817/ijet/2018/v10i6/181006046

[7] Azevedo, J., \& Portela (2014, November 29). Como se define o contexto de uma escola e aquilo que se espera dela? $O$ Público. Retrieved from https://www.publico.pt/2014/11/29/sociedade/analis e/contexto-e-valor-esperado-do-contexto-1677516

[8] Hornemann, J. (1974). Influence du contenu sur la résolution de problèmes logiques. Enfance, 27, 4564.

[9] Costa, J. M., \& Miranda, G. L. (2019). Using Alice Software with 4C-ID Model: Effects in Programming Knowledge and Logical Reasoning. Informatics in Education, 18(1), 1-15.

doi: https://doi.org/10.15388/infedu.2019.01. 
